\title{
Preliminary Evaluation of Method to Monitor Landfills Resilience against Methane Emission
}

\author{
Noor Amalia Chusna ${ }^{1, *}$, Maryono Maryono ${ }^{2}$ \\ ${ }^{1}$ Master Program of Environmental Studies, School of Postgraduate Studies Diponegoro University, Semarang-Indonesia \\ ${ }^{2}$ Departemen of Urban and Regional Planning, Faculty Engineering, Diponegoro University, Semarang-Indonesia
}

\begin{abstract}
Methane emission from landfill sites contribute to global warming and un-proper methane treatment can pose an explosion hazard. Stakeholder and government in the cities in Indonesia been found significant difficulties to monitor the resilience of landfill from methane emission. Moreover, the management of methane gas has always been a challenging issue for long waste management service and operations. Landfills are a significant contributor to anthropogenic methane emissions. This study conducted preliminary evaluation of method to manage methane gas emission by assessing LandGem and IPCC method. From the preliminary evaluation, this study found that the IPCC method is based on the availability of current and historical country specific data regarding the waste disposed of in landfills while from the LandGEM method is an automated tool for estimating emission rates for total landfill gas this method account total gas of methane, carbon dioxide and other. The method can be used either with specific data to estimate emissions in the site or default parameters if no site-specific data are available. Both of method could be utilize to monitor the methane emission from landfill site in cities of Central Java.
\end{abstract}

\section{Introduction}

Global Climate Change is one of the un-expected and then to be dangerous and irreversible magnitude of climate impact. Several aspects of these climate impacts are already noticed: global warming, sea level rise, intense rain, as well as more frequent and severe heat waves. Many nations around the world have been developing innovative policies and business approaches to build low-carbon economies and adapt to changing climate. In particular, control of greenhouse gas emission from various sources. Several global effort have been made to understand, quantify, and manage greenhouse gas emissions. Major actions have been taken to stabilize the green house gas concentrations in the atmosphere to prevent the dangerous climate change impact [1].

Methane $\left(\mathrm{CH}_{4}\right)$ is the second most important anthropogenic greenhouse gas after carbon dioxide (CO2). Per mass of the compound has been estimated to be more than 28 times of that of carbon dioxide [2]. Globally, over $60 \%$ of total methane emissions come from human activities $[3,4]$. Mostly, methane is emitted from industry, agriculture, and waste management activities. Methane emissions from waste management are dominated by the decomposition of organic matter.

Landfill sites produced landfill gas (LFG) which containing decomposable organic waste. The major components of LFG are methane and carbon dioxide, as a product of the biological decomposition of organic material. Despite the impact, methane is very potential to explore as an energy alternative resource [5]. Landfills are one of the main anthropogenic biogenic emissions of $\mathrm{CH}_{4}$ [6], and still one of the most common waste management option globally [7]. In developing countries $\mathrm{CH}_{4}$ emissions from landfills rapidly increase because of rapid population growth and accelerated urbanization process [8].

The characterization of landfill emissions is a complicated task, primarily because emissions are the result of a complex matrix of biological, physical, and engineering factors (i.e. $\mathrm{CH}_{4}$ generation, oxidation, migration, storage, and recovery) [9]. These factors depend on parameters such as organic content, age and distribution of the waste $[10,11]$, climate [12], and soil cover properties (e.g. water content, nutrient availability, $\mathrm{pH}$, texture, porosity, fissures, and cracks) $[13,14,15]$. Given the number and variability of these factors, $\mathrm{CH}_{4}$ emissions can vary greatly spatially and temporally.

Landfills gas could be generated by the biologically breaking down processes of waste components [16]. The production of landfill gas depends on the quantity and composition of the disposed waste [12], i.e., the content of organic waste and its degradability. In general, landfill gas is mainly

\footnotetext{
Corresponding author: chusna.amalia95@gmail.com
} 
composed by $\mathrm{CH}_{4}$ and $\mathrm{CO} 2(50 \%-60 \%$ and $40 \%-$ $45 \%$, respectively), although $\mathrm{N}_{2}, \mathrm{O}_{2}, \mathrm{H}_{2} \mathrm{~S}, \mathrm{NH}_{2}$ and more than two hundred organic compounds are also present [17]. Landfill gas production also depends on waste age and other parameters, such as temperature, water content, nutrients, and inhibiting compounds [18]. Young landfills (5-30 years) produce gas with higher methane content $(30 \%-60 \%)$ than older landfills [19].

Various researchers have reported the spatial variability of methane emissions. Several researchers illustrated the high spatial variation in emissions, caused by the high heterogeneity of waste. Emissions at one spot can be 1000 fold of emissions from a spot a located a few meters away [20]. There is no correlation between emission at a spot at the landfill and the emission six meters away [21]. Moreover, They estimate that $50 \%$ of emissions are released at $5 \%$ of the landfill surface. Other research found and estimate that $70 \%$ of methane emissions are released through short cuts [22]. The typical distribution of methane emissions at a landfill is similar patterns [23], but there are some variation emissions in the square meter at a small scale emissions $[20,24,25]$.

Refers to the condition, this study is proposed to comparing and assessing of method to estimate methane missions in a landfill. This study evaluated two method such as LandGEM [26], and using gas prediction of the Guidelines for National Greenhouse Gas Inventories [8].

\section{Method to monitor landfills resilience against methane emission}

\subsection{IPCC Method}

The IPCC developed two methods for estimating methane emissions from MSW landfills in each country: the default method and the FOD method $[27,8]$. The default method is based on a mass balance approach, which estimates total national emissions based on a number of constant empirical parameters. The FOD method estimates the change of methane emissions with time. This method assumes that the degradable organic carbon (DOC) in waste decays slowly over a few decades when $\mathrm{CH}_{4}$ is formed. The most appropriate method is based on the availability of current and historical country specific data regarding the waste disposed of in landfills. The methane emissions for each region can be calculated as follows :

$$
\begin{gathered}
\mathrm{ECH}_{4}=\sum_{\mathrm{T}}\left(\left(\mathrm{e}^{-(\mathrm{T}-1) \mathrm{k}}-\mathrm{e}^{-\mathrm{Tk}}\right) \times \mathrm{MSW} \times \mathrm{MCF} \times\right. \\
\text { DOC x DOCf x F x 16/12-R) x (1-OX) } \\
\mathrm{K}=(\ln 2) / \mathrm{t} 1 / 2
\end{gathered}
$$

where $\mathrm{ECH}_{4}$ represents the methane emissions from a MSW landfill, T is the inventory year for which emissions are calculated, $\mathrm{k}$ is the reaction rate constant, $\mathrm{t} 1 / 2$ is the half-life of methane, MSW is the total MSW disposed of in the landfill, MCF is the methane correction factor based on the method of disposal and depth available at the landfill, DOC is the fraction of degradable organic carbon in the MSW, DOCf is the fraction of total DOC that actually degrades, $\mathrm{F}$ is the fraction of methane in the landfill gas, 16/12 is the conversion ratio $\left(\mathrm{CH}_{4} / \mathrm{C}\right), \mathrm{R}$ is the methane recovered value, and $\mathrm{OX}$ is the oxidation factor. The values of the parameters used here were derived from the IPCC [8], and the latest research results and local emissions factors.

On the basis of the evaluation of the methane formation potential in landfill site are estimated. The gas prediction is carried out via a 1st order approach of the IPCC Guidelines for National Greenhouse Gas Inventories [8]. The results from the gas modeling show that the primary gas production already takes place during the filling phase and the first years of the closure phase. As, particularly in this phase, only minor methane oxidation in the upper waste layers can be assumed, the highest emissions occur during this time. They decrease significantly with the application of a surface cover or a surface sealing system designed for methane oxidation.

\subsection{LandGEM Method}

LandGem is an automated tool for estimating emission rates for total landfill gas, methane, carbon dioxide and can be used either with site specific data to estimate emissions or default parameters if no sitespecific data are available. LandGem contains two sets of default parameters. The CAA defaults are based on requirements for MSW landfills laid out by the Clean Air Act (CAA), including the inventory defaults based on emission factors in the U.S. Environmental Protection Agency's (EPA's) Compilation of Air Pollutant Emission Factors (AP42). This set of defaults yields average emissions can be used to generate emission estimates for use in emission inventories and air permits in the absence of site specific test data. LandGem is based on a firstorder decomposition rate equation for quantifying emissions from the decomposition of landfilled waste in MSW landfills and to estimate annual emissions over a time period based on user specification. The equation which is carried out is as follows [11]:

$$
\mathrm{QCH}_{4}=\sum_{\mathrm{i}=1}^{\mathrm{n}} \sum_{\mathrm{j}=0.1}^{1}\left(\frac{\mathrm{Mi}}{10}\right) \mathrm{e}^{-\mathrm{k} \text { tq }}
$$

Where $\mathrm{QCH}_{4}=$ annual methane generation in the year of the calculation (m3/year); $i=1$ year time increment; $\mathrm{n}=$ (year of the calculation) - (initial year of waste acceptance); $j=0.1$ year time increment; $\mathrm{k}=$ methane generation rate $\left(\right.$ year $\left.^{-1}\right) ; L 0=$ potential methane generation capacity, meter cube per metric ton $\left(\mathrm{m} 3 / \mathrm{t}^{-1}\right)$.This factor depends on rate of decay and composition of waste $; \mathrm{Mi}=$ mass of waste accepted in year $(\mathrm{t})$; $\mathrm{tij}=$ age of the section of waste mass Mi accepted in the year (decimal years, e.g. 3.2 years) [11]. L0 factors use Clean Air Act (CAA) default values for the measurement of the parameters [11]. Methane generation rate (k) has default value $0.04 \mathrm{yr}-$ 
1 for areas receiving $635 \mathrm{~mm}$ or more annual rainfall precipitation and $0.02 \mathrm{yr}-1$ forareas receiving less than $635 \mathrm{~mm}$ and $0.30 \mathrm{yr}-1$ for wet landfills [11,28]. Potential methane generating capacity (L0), depend on the land fill site, waste composition and ultimate methane yield of each component have default values ranging from 6 to $270 \mathrm{~m} 3 / \mathrm{t}-1[11]$.

Comparative studies showed that emission models may give different results, even when employed input-data are the same. Some comparison methane emission models with methane emission measurements has been conducted by J. Jacobs et, all [29]. They showed that emission models resulted into high divergent estimations. They also stated that in the near future further development of methane emission measurement techniques may provide more reliable tools than modeling The methane output score is calculated by comparing the predicted methane output rate to the actual methane output rate for a given site. The methane output is predicted using the LandGEM model for the ideal methane output. The score is expressed as the percentage deviation from the predicted value:

$$
\mathrm{Mx}, \mathrm{t}=(\mathrm{Ba}-\mathrm{Bi}) / \mathrm{Bi}
$$

Where $M$ is the methane output score for site ' $x$ ' at time ' $\mathrm{t}$ ', 'BA' the actual methane output (m3/yr) and ' $\mathrm{BI}$ ' the ideal value for methane output (m3/yr). Therefore, a score of $0 \%$ represents the actual methane output being equivalent to predicted output. The methane output score is given a red, yellow or green light to highlight good, average or poor methane output rate. A green light indicates a score higher than $30 \%$ which is determined by defining the error margin of the LandGEM model to be $30 \%$ either side of the actual score [20]. A yellow light represents a score of $-30 \%$ to $30 \%$ whilst a red light represents a score below $-30 \%$. The boundaries over which red, yellow and green lights are given can be changed in further versions of the model.

\section{Methodology}

This study is quantitative evaluation research which uses two possibility method to monitor the landfill resilience against methane emission. Landfill site sample is selected according to the availability of data requirement from those parameter of two method methane emission calculation in Indonesia. This study selected at least 10 landfills in Indonesia's cities.

\section{Result and discussion}

This study comparing the IPPC method and LandGem Method to monitor methane emission. The perspective of resilience here associated to engineering and ecological resilience at which the landfills site methane emission could be assess and account by the method [30]. In practical to achieved the landfill resilience, the stakeholder intention must be assess.
There some factor concerning the stakeholder knowledge [31]. Moreover in the context of disaster event a huge disaster waste will be discharge to the landfill site

The engineering resilience refers to the amount of the methane emission that could be account, while ecological resilience associated to the degree of environmental degradation such as climate change impact due to increasing of methane.

This study shown that both of the method could be use to calculate and assess the amount of methane emission. Such as shown in table 1, both of method methane emission have a positive correlation with capacity of methane, at which more bigger capacity of landfill also more bigger methane emission. According to the calculation, the bigger of methane calculation is Bantargebang landfill with total emission of $\mathrm{CO} 2$ are estimated $79.2 \mathrm{E}^{+06} \mathrm{~m} 3$ per year by using IPPC method and estimated $49.68 \mathrm{E}^{+06}$ by using landGem method. Table 1 shown that the emission number by using IPPC method is more bigger comparing to the LandGem Method. The varian of the differences from each landfill sample is vary from $30 \%$ until $90 \%$. According to the result the two method could not be use in same time due to the high of deviation.

Table 1. Comparison calculation of methane emission by using IPPC and LandGEM Method in several landfill in Indonesia.

\begin{tabular}{|c|c|c|c|c|}
\hline \multirow{3}{*}{ No } & \multirow{3}{*}{ Landfill } & \multirow{3}{*}{$\begin{array}{c}\text { Landfill } \\
\text { Capacity } \\
x 1000 \text { ton }\end{array}$} & \multicolumn{2}{|c|}{ Method o } \\
\hline & & & IPCC & LandGEM \\
\hline & & & m3/year & m3/year \\
\hline 1 & $\begin{array}{l}\text { TPA Supit } \\
\text { Urang, } \\
\text { Malang }\end{array}$ & 4,800 & $6.6 \mathrm{E}^{+06}$ & $4.14 \mathrm{E}^{+06}$ \\
\hline 2 & $\begin{array}{l}\text { TPA Galuga } \\
\text { Cibung } \\
\text { bulang, Bogor }\end{array}$ & 5,000 & $10.42 \mathrm{E}^{+06}$ & $6.7 \mathrm{E}^{+06}$ \\
\hline 3 & $\begin{array}{l}\text { TPST } \\
\text { Bantargebang, } \\
\text { Bekasi }\end{array}$ & 28,800 & $79.2 \mathrm{E}^{+06}$ & $49.68 \mathrm{E}^{+06}$ \\
\hline 4 & $\begin{array}{l}\text { TPA } \\
\text { Jatibarang, } \\
\text { Semarang }\end{array}$ & 3,360 & $8.66 \mathrm{E}^{+06}$ & $5.47 \mathrm{E}^{+06}$ \\
\hline 5 & $\begin{array}{l}\text { TPA } \\
\text { Banyuurip, } \\
\text { Magelang }\end{array}$ & 8900 & $2.06 \mathrm{E}^{+06}$ & $1.33 \mathrm{E}^{+06}$ \\
\hline 6 & $\begin{array}{l}\text { TPA } \\
\text { Jeruklegi, } \\
\text { Cilacap }\end{array}$ & 4,220 & $8.25 \mathrm{E}^{+06}$ & $5.17 \mathrm{E}^{+06}$ \\
\hline 7 & $\begin{array}{l}\text { TPA Bestari, } \\
\text { Probolinggo }\end{array}$ & 5,250 & $10.48 \mathrm{E}^{+06}$ & $6.57 \mathrm{E}^{+06}$ \\
\hline 8 & $\begin{array}{l}\text { TPA } \\
\text { MuaraFajar, } \\
\text { Pekanbaru }\end{array}$ & 1,400 & $6 \mathrm{E}^{+06}$ & $3.6 \mathrm{E}^{+06}$ \\
\hline 9 & $\begin{array}{l}\text { TPA Basirih, } \\
\text { Banjarmasin }\end{array}$ & 1,200 & $4.8 \mathrm{E}^{+06}$ & $3.1 \mathrm{E}^{+06}$ \\
\hline 10 & $\begin{array}{l}\text { TPA Benowo, } \\
\text { Kota Gresik }\end{array}$ & 13,800 & $38 \mathrm{E}^{+06}$ & $23.88 \mathrm{E}^{+06}$ \\
\hline
\end{tabular}

According to the calculation, each of method have a different characteristic. In practical the two method have some specific function and parameter that could 
not be comparing due to their characteristic of data and parameter that utilize for assessment. Moreover, the characteristic of engineering resilience or ecological resilience in practical monitoring of methane emission could not be comparison. Both of method have a difference characteristic and parameter concerning to engineering resilience and ecological resilience.

\section{Conclusions}

1. Method monitoring the estimate methane emissions can be using predicted using the LandGem. The calculation is based on user input of age, waste acceptance and potential methane generation capacity (L0). The methane output is predicted using the LandGEM model for the ideal methane output.

2. Method monitoring the estimate methane emissions can be using gas prediction IPCC. The results from the gas modelling show that the primary gas production already takes place during the filling phase and the first years of the closure phase.

\section{Acknowledgment}

This research is funded by the Directorate of Research and Community Services, Ministry of Research, Technology and Higher Education for year 2017 with contract number 344-42/UN7.5.1/PP/2017

\section{Reference}

1 Kormi, Tarek., Mhadhebi, Safa., Aji, NizarBel Haj., Abichou, Tarek., Green, Roger. Waste Management, (2016)

2 IPCC, Climate Change 2013: The Physical Science Basis, Contribution of Working Group I to the Fifth Assessment Report of the Intergovernmental Panel on Climate Change, 1535, (2013)

3 EPA, Methane and Nitrous Oxide Emissions From Natural Sources. U.S. Environmental Protection Agency, Washington, DC, USA, (2010)

4 E. Nisbet, E. Dlugokencky, P. Bousquet, Methane on the rise-again. Science $\mathbf{3 4 3}$ (6170), 493-495, (2014)

5 Conestoga-Rovers and Associates, Landfill Gas Management Facilities Design Guidelines, British Columbia, Ministry of Environment, (2010)

6 M. Yang, Y. Xue, Y. Jiang, K. Wang, Y. Zhao, J. China Coal Soc. 34, 1349e1353, (2009)

7 L. Ziyang, W. Luochun, Z. Nanwen, Z. Youcai, Martial 651 recycling from renewable landfill and associated risks: a 652 review. Chemosphere 131:91-103,

(2015) http://dx.doi.org/10.1016/j. chemosphere.2015.02.036.654

EPA, Global Mitigation of Non-CO2 Greenhouse Gases: 2010-2030. U.S. Environmental Protection Agency, Washington, DC, USA, (2014)

9 K. Spokas, J. Bogner, J. Chanton, J. Geophys. Res.: Biogeosci. 116 (G4).n/a-n/a, (2011)

10 I. Georgaki, P. Soupios, N. Sakkas, F. Ververidis, E. Trantas, F. Vallianatos, T. Manios, Sci. Total Environ. 389 (2-3), 522531, (2008)

11 USEPA (Unites States Environmental Protection Agency), Landfill Gas Emissions Model (LandGEM) Version 3.02 User's Guide. (PDF) (56 pp., $1.4 \mathrm{Mb}$ ) Publication No. 600/R-05/047,(2005)

$<$ http://www.epa.gov/ttncatc1/dir1/landgemv302-guide.pdf $>$ (accessed 29.07.2015).

12 J. Chanton, T. Abichou, C. Langford, G. Hater, R. Green, D. Goldsmith, N. Swan, Sci. Technol. 45 (1), (2011)

13 J. Bogner, K. Spokas, Landfills. In: Reay, D., Smith, P., Van Amstel, A. (Eds.), Methane and Climate Change. Routledge, London \& Washington, D.C., pp. 175-200, (2010)

14 J. Gebert, I.U. Roewer, H. Scharff, C.D.L. Roncato, A.R. Cabral, Waste Manage. 31 (5), 987-994, (2011)

15 L. Giani, J. Bredenkamp, I. Eden, J. Plant Nutr. Soil Sci. 165 (2), 205-210, (2002)

16 D. Widory, E. Proust, G. Bellenfant, O. Bour, Waste Manag. 32:1685-1692. (2012). http://dx.doi.org/10.1016/j.wasman.2012.04.00 8

17 A. Beylot, J. Villeneuve, G. Bellenfantat, Waste Manag. 33: 401-411. (2013). http://dx.doi.org/10.1016/j.wasman.2012.08.01 7.54 .

18 C. Scheutz, A.M. Fredenslund, J. Nedenskov, J. Samuelsson, P. Kjeldsen, Waste Manag. 31:946-955, http://dx.doi.org/10.1016/j.wasman.2010.10.02 1.

19 O.P. Karthikeyan, S.Y.M. Jane, R. Technol. 217:205-209, (2016). http://dx.doi.org/10.1016/j.biortech.2016.01.05 9

20 H. Oonk, Innovat. Environ. Technol. 75, (2010)

21 P.M. Czepiel, J.H. Shorter, B. Mosher, E. Allwine, J.B. McManus, R.C. Harriss, C.E. Kolb, B.K. Lamb, Waste Manage. 23, 593598, (2003)

22 P. Bergamaschi, C. Lubina, R. Konigstedt, H. Fischer, A.C. Veltkamp, O. Zwaagstra, J. Geophys. Res.-Atmosph. 103, 8251-8265, (1998) 
23 A.N. Nozhevnikova, A.F. Lifshitz, V.S. Lebedev, G.A. Zavarin, Chemosphere 26 (14), 401-417, (1993)

24 K.R. Mackie, C.D. Cooper, Environ. Model.Softw. 24, 1223-1232, (2009)

25 I. Rachor, J. Streese-Kleeberg, J. Gebert, 2009. Proceedings Sardinia 2009, Twelfth International Waste Management and Landfill Symposium, S. Margeritha di Pula, Cagliari, Italy; 5-9 October 2009

26 Emkes, Harriet., Coulon, Frederic., Wagland, Stuart., Waste Management, (2015)

27 S. Kumar, S. Gaikwad, A. Shekdar, P. Kshirsagar, R. Singh, Atmos Environ, 38:3481-7, (2004)
28 H.R. Amini, D.R. Reinhart, Waste Manage. 31, 2020-2026, (2011)

29 J. Jacobs, H. Scharff, Comparison of Methane Emission Models and Methane Emission Measurements. Workshop on Inventories and Projections of Greenhouse Gas Emissions from Waste, EEA, Copenhagen, Denmark, (2005)

30 CS Holling - Engineering within ecological constraints, 1996

31 Maryono, H. Nakayama, T. Shimaoka, Memoir of faculty Engineering, Kyushu Univeristy, Vol.74 no 3, pp.79-98 